\title{
Erratum: An innate defense peptide BPIFA1/SPLUNC1 restricts influenza A virus infection
}

KM Akram, NA Moyo, GH Leeming, L Bingle, S Jasim, S Hussain, A Schorlemmer, A Kipar, P Digard, RA Tripp, RV Shohet, CD Bingle and JP Stewart

Mucosal Immunology (2018) 11, 1008; doi:10.1038/mi.2017.109

Correction to: Mucosal Immunology advance online publication, 17 May 2017; doi:10.1038/mi.2017.45

This article was originally published under NPG's License to Publish, but has now been made available under a [CC BY 4.0] license. The PDF and HTML versions of the paper have been modified accordingly.

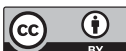

This work is licensed under a Creative Commons Attribution 4.0 International License. The images or other third party materialin thisarticleareincluded in thearticle's CreativeCommonslicense, unlessindicated otherwisein the creditline; if the material is not included under the Creative Commons license, users will need to obtain permission from the license holder to reproduce the material. To view a copy of this license, visit http://creativecommons.org/licenses/by/4.0/

(C) The Author(s) 2018 